\title{
A place-based turn in multifunctional agriculture: The case of Italy's Garfagnana region
}

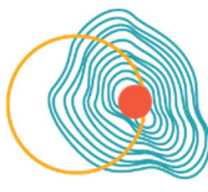

PLACE-BASED FOOD SYSTEMS CONFERENCE:

Making the Case, Making it Happen August 9-10th, 2018

Jordan Treakle *

Food and Agriculture Organization of the United Nations

Submitted December 15, 2018 / Revised April 1, May 13, and June 15, 2019 / Accepted June 17, 2019 /

Published online August 23, 2019

Citation: Treakle, J. (2019). A place-based turn in multifunctional agriculture: The case of Italy's Garfagnana

region. Journal of Agriculture, Food Systems, and Community Development, 9(Suppl. 1), 179-195.

https://doi.org/10.5304/jafscd.2019.091.039

Copyright (C) 2019 by the Author. Published by the Lyson Center for Civic Agriculture and Food Systems. Open access under CC-BY license.

\begin{abstract}
The Garfagnana region of Tuscany has witnessed a resurgence in the small-scale farming sector.

Rooted in a historical practice of multifunctional agriculture, over the last decade family farmers and local institutions have increasingly focused on place-based development initiatives, such as revalorizing native livestock breeds and promoting agroecological practices, as ways to strengthen small-scale agriculture and the local rural economy. This place-based turn is now reshaping the development trajectories of many family farms and communities in Garfagnana.

Drawing on qualitative field research conducted in 2015, this paper utilizes the sociological

* Jordan Treakle, Food and Agriculture Organization of the United Nations, Viale delle Terme di Caracalla; Rome 00153, Italy; Itreaks@gmail.com
\end{abstract}

\section{Author Note}

The views expressed in this paper are those of the author and do not necessarily reflect the views of the Food and Agriculture Organization of the United Nation. conceptual lenses of multifunctional agriculture and place-based development to analyze three casestudy farms, each with different production systems and territorial relations. Multifunctional agriculture theory is used to analyze how farming practices in the three case-studies represent a range of adaptive shifts away from productionist trends and toward a more diversified farming approach. Then place-based theory is used to demonstrate how these multifunctional agriculture practices relate to the distinct socio-ecological landscape of Garfagnana, uniquely rooting these farms in the territory. This article ultimately examines how new forms of multifunctional agriculture are fostering a place-based food and agriculture system in central Italy and how this approach can strengthen family farming and rural communities.

\section{Keywords}

Family Farming, Multifunctional Agriculture, Place-Based Development, Territorial

Development, Agroecology 


\section{Introduction}

The Garfagnana region of northern Tuscany, located between the Apuan Alps and the Apennine mountain ranges of central Italy, has witnessed a resurgence of the small-scale family farming sector. ${ }^{1}$ Despite the general trend in Italy (and, more broadly, in Europe) of rural abandonment and agricultural concentration since the 1980s, much of the farming sector in Garfagnana continues to be oriented toward small-scale production. This development trajectory is a result (in part) of efforts by local farmers and institutions both to strengthen historically rooted agricultural practices and values and adapt these practices to new socio-economic and environmental dynamics in the territory ${ }^{2}$ (Camilli \& Pieroni, 2016; Rovai \& Andreoli, 2016). With growing European socio-political recognition of the diverse social, environmental, cultural, and economic roles and functions that small-scale agriculture plays in rural communities, Garfagnana has been increasingly recognized for its family-farming sector and approach to community-oriented development as a potential model for other regions. Academic research in Garfagnana has illustrated some of these dynamics, using multifunctional agriculture theory. But continued adaptive changes by farmers in Garfagnana, particularly over the past five to ten years, are not effectively explained by this theory. Therefore, building on past research on the multifunctional nature of the Garfagnana farming sector ${ }^{3}$, this paper argues that multifunctional agriculture in Garfagnana is increasingly taking a place-based turn, which is reshaping the development trajectories of many family farms and communities in the territory.

Drawing on qualitative field research conducted primarily in 2015, this paper utilizes the sociological conceptual lenses of multifunctional agriculture and place-based development to analyze three case-study farms, each of which demonstrate different elements of place-based multifunctional agriculture in Garfagnana. For this analysis, multifunctional agriculture theory is used to consider how each case-study farm represents a range of adaptive shifts away from agricultural productionist trends, and toward a diversified farming approach oriented around non-capitalistic practices. Placebased theory is used to demonstrate how these multifunctional agriculture practices engage local histories, relationships, and materialities to embed farms in place-based identities and geographies, and in turn reshape community development trajectories in Garfagnana. The core research question therefore focuses on how new forms of multifunctional agriculture in Garfagnana are fostering a place-based food and agriculture system. In exploring this question, the paper's contribution to this field of study is to deepen understandings of how multifunctional agriculture is changing and becoming increasingly relational (in terms of socioecological relations) and place-based, as well as provoking discussion of how these emerging forms of community-based development (in terms of practices, relations and policies) can support the family-farming sector.

\section{Theoretical Framework}

Two theoretical lenses are used to analyze the casestudy farms and build the argument for a placebased turn in the multifunctional agriculture practices of Garfagnana. A dual lens approach has been chosen in part to recognize criticism of multifunctional agriculture theory as too narrow in its analytical scope, focusing primarily on on-farm activities while leaving conceptualization of the off-farm context under-analyzed (Cairol et al. 2009; Huylenbroeck, Vandermeulen, Mettepenningen, \& Verspecht, 2007). By coupling multifunctional agriculture theory with place-based theory, this paper aims to illuminate how on-farm practices are

\footnotetext{
${ }^{1}$ For the purposes of this paper, 'small-scale,' 'family,' and 'peasant' agriculture are used interchangeably. This is due to the fact that the farmers interviewed for this research in Garfagnana used 'family farmer' and 'small-scale farmer' terminology to describe themselves. The term 'peasant' is used here in reference to the extensive literature on new peasantries in Europe (primarily inspired by the work of J.D. van der Ploeg), which both informs the theoretical framework and closely relates to the farms of this research. 2 For the purposes of this paper, the term 'territory' is conceptualized as a dynamic socio-ecological area of cooperation, defined loosely by local actors in that area (Bocher, 2005). For further discussion see Cairol, Caudel, Nickel, Caron, and Kroger (2009). ${ }_{3}^{3}$ For additional research on multifunctional agriculture in Garfagnana, see Camilli \& Pieroni (2016); Mantino \& Vanni (2018); Rovai \& Andreoli (2016).
} 
"embedded in new networks" (Ploeg \& Roep, 2003, p. 4) of the off-farm territory, and provide a new perspective on multifunctional agriculture and placebased development in the Garfagnana context.

The first theoretical lens of this paper is multifunctional agriculture, which takes a holistic perspective on agricultural practices by recognizing the intersectionality of farming in providing sociocultural, environmental, and economic benefits, as well as material sustenance, to producers and rural communities (Huylenbroeck et al., 2007). According to Cairol et al. (2009), multifunctional agriculture theory "differs from other approaches in that it takes the interrelations between several functions fulfilled under the umbrella of a single activity... [and]... places these interrelations centre-stage" (p. 275). The theory emerged into mainstream research and policy circles in Europe in the early 1990s as a response to the reductionist perspective of farm transition theory and the narrow productionist goals of the Common Agriculture Policy's agricultural modernization agenda in Europe (Cairol et al., 2009; Ploeg \& Roep, 2003). As the concept evolved in both academic and policy circles, Wilson (2008) developed a more defined theoretical framework for multifunctional agriculture, emphasizing a spectrum of productionist and non-productionist activities with social, environmental, and non-capitalist characteristics, which can be evaluated at the individual farm level (Cairol et al., 2009; Ploeg \& Roep, 2003). In this framework, Wilson (2008) described the main characteristics of strong multifunctional farms ${ }^{4}$ :

- Strong social, economic, cultural, moral, and environmental capital

- Strong tendency for local and regional embeddedness in local governance structures

- High environmental sustainability

- Focus on relocalized agro-food chain

- Low farming intensity and productivity

- Production of foods with high, often regionally based, symbolic characteristics

- Farm diversification activities that lead to reduced farm production activity
- Weak integration into the global capitalist market

- Substantial changes in the expressed philosophical understanding of the role of farming outside of traditional productivist food and fiber activities

Wilson (2008) acknowledges that these characteristics of multifunctionality "may often represent a theoretical ideal rather than a fully achievable goal. ... It would be rare to achieve strong multifunctionality for all indicators highlighted above" (pp. 2-3). Thus, a farm does not have to exhibit all the multifunctional characteristics to be considered a strong multifunctional farm.

In addition to its contribution to rural sociological theory, the concept of multifunctional agriculture "has become a leading paradigm for creating a framework for explaining policy actions, mainly in Europe" (Huylenbroeck et al., 2007, p. 24). Perhaps most significantly, the reform of the Common Agriculture Policy in 2000 adopted language recognizing multifunctional farming as part of European agriculture systems (Huylenbroeck et al., 2007; Knickel, Renting, \& Ploeg, 2004; Wilson, 2007). This policy history is relevant to this research for two reasons: first, following the inclusion of multifunctional farming in the 2000 Common Agriculture Policy reform, the Italian government placed significant emphasis on the concept in its national and sub-regional agriculture policies, linking multifunctional agriculture to the concept of territoriality and sustainable agricultural development in an effort to strengthen the country's investment in small-scale and diversified farms (Cairol et al., 2009). Second, as discussed below, local government institutions in Garfagnana have played an increasingly important role in supporting multifunctional and place-based agricultural initiatives, which again must be considered within the broader policy environment of the Common Agriculture Policy and its promotion of multifunctional agriculture across the European Union.

The second theoretical lens of the paper draws on place-based theory to analyze the case-study farms and their relational links with the broader

4 Wilson (2008) contrasts weak agricultural multifunctionality as being the inverse of these characteristics (p. 2). 
territory. Place-based theory is diverse, drawing on a wide range of perspectives from feminist, rural sociology, and political geography literature (Healey \& Jones, 2012; Massey, 2004). The cross-pollination of these disciplines in place-based theory has fostered new ways of understanding place, moving away from seeing place as a static topographic space to reconceptualizing it as a more fluid and heterogeneous network of social relations and practices linked across geographies (Halfacree, 2014; Harvey, 1994; Massey, 1994, 2005; Ray, 2002). For example, Massey and Escobar have articulated place as a "dimension of multiplicity" (Massey, 2004, p. 14) which is "constituted by sedimented social structures and cultural practices" (Escobar, 2001, p.143) and emplaced or enacted through the individuals that identify with that place (Escobar, 2001). Likewise, Pickerill and Chatterton (2006) state that places are open "entanglements and configurations of multiple trajectories, multiple histories" that are "always contested and fractured, contradictory, and overlapping" (pp. 736-737). These more fluid and relational perspectives on place have allowed issues such as power hierarchies and rural identities to be more explicitly examined in research related to agriculture policy and rural development.

In addition to these socio-cultural components of the concept of place, there is also an important socio-ecological element in place-based theory, emphasizing how natural resources and economies of exchange shape places. A relevant academic perspective is that of Richardson and Weszkalnys (2014), who see natural resources not simply as static goods or assets that societies exploit through extraction, but, rather, conceptually as materialities, to which society gives (social, economic, and cultural) value and thus are "always informed by the historical, social, and material environments within which resource matters are constituted" (p. 15). As societal (re)valorization of different natural resources changes over time, natural resource economies in turn shape societal identities and socioecological relations in different ways. Therefore the interaction between natural resources and society is relational and always in flux: "The processes of resource extraction generate a constant reworking of the boundaries between nature and culture"
(Richardson \& Weszkalnys, 2014, p. 8). This conceptualization of natural resources is closely linked to the relational socio-cultural understandings of place discussed above. The common threads among these place-based perspectives coalesce around the idea that places are dynamic territorial fora (with loose ecological boundaries) in which identities, practices, relations, and materialities are negotiated, shaped, and exchanged.

This paper uses multifunctional agriculture and place-based theory complementarily, illustrating that for many of the Garfagnana case-study farms, socio-ecological relations in the form of nonproductionist farming practices are changing, often increasingly linked to the specific socio-ecological geography of the territory. At the same time, the socio-cultural boundaries of Garfagnana are being increasingly shaped by these emerging place-based agro-ecological practices, particularly as local institutions seek to promote a territorial (agricultural) identity. While multifunctional agriculture theory examines social, economic, cultural, moral, and environmental capital at the farm level, this analytical approach does not adequately capture these territorial dynamics in Garfagnana and falls short in explaining how socio-ecological relations shape farm practices and regional development trajectories. Place-based theory thus plays an important role in understanding how multifunctional agriculture practices in Garfagnana are embedded in a broader territorial shift toward place-based development, by examining the values of farmers and their relations to the land, agriculture, and broader communities.

\section{Methodology}

The three case-study farms of this research were analyzed for practices of multifunctional agriculture and place-based characteristics. The farm data for this analysis was collected through mixed-method qualitative research, based on the Rapid Rural Assessment methodology (McCracken, Pretty, \& Conway, 1988). First, the three case-study farms were selected from a larger set of six rural enterprises in Garfagnana visited in July 2015. The three farms, Maestà della Formica, Azienda Agricola Cerasa, and Societa' Agricola Filippi, were chosen because each exhibits different characteristics of 
agricultural change, but also represents the ongoing territorial shift toward place-based multifunctional agriculture in Garfagnana. Each farm was visited by the researcher in July 2015, and farmers were asked semi-structured interview questions in both focus group sessions and one-on-one conversations. In almost all cases, a translator was used to interpret farmer responses from Italian to English.

In addition to the farmer interviews, this paper also draws on qualitative information collected through interviews with other agricultural stakeholders, such as local administrators and agronomists in the region.

Because almost all data received from the interviews was provided through personal narra-

Figure 1. The Garfagnana Territory, Located in the Northwest Corner of the Province of Lucca, Tuscany

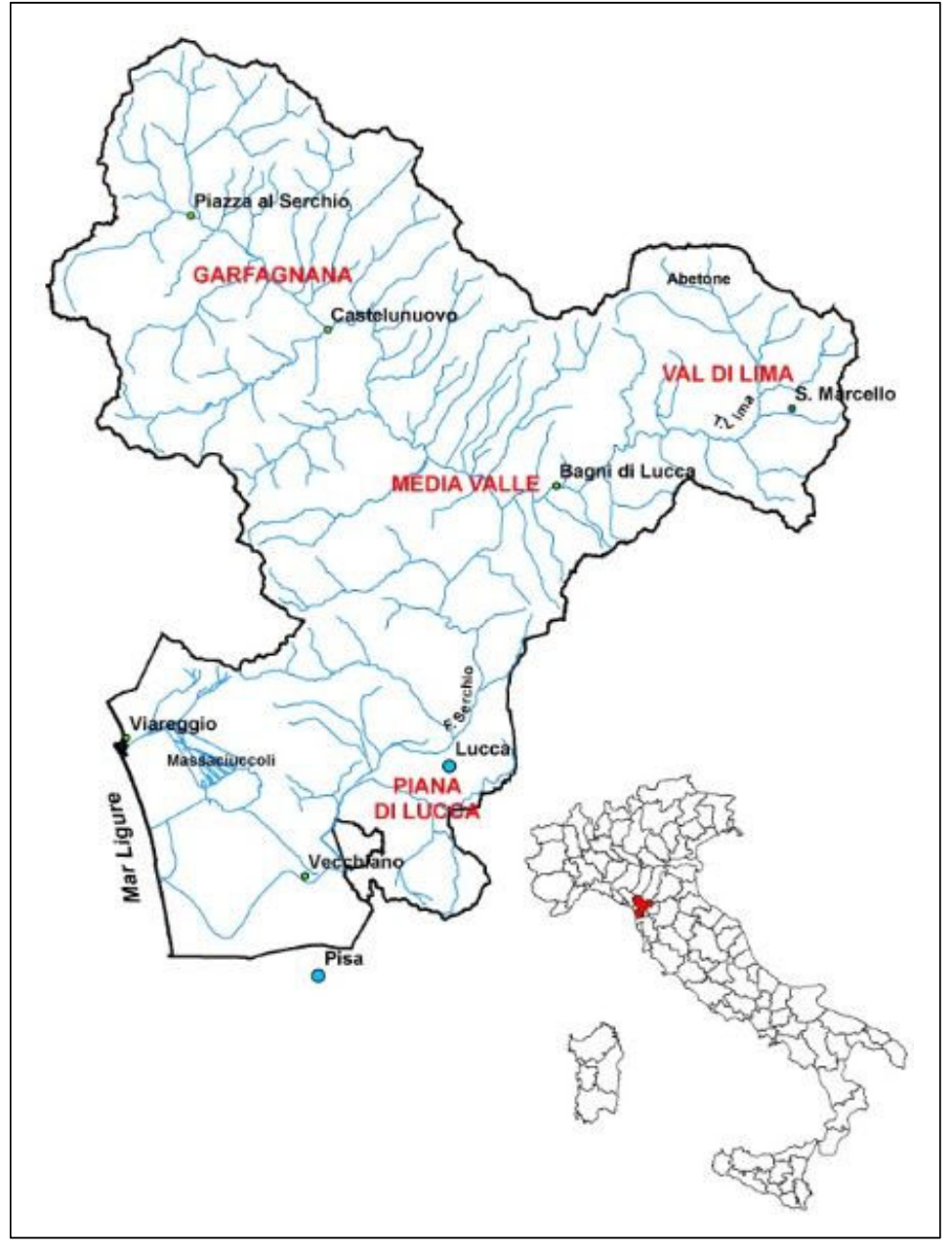

Source: Autorità di Bacino Pilota del Fiume Serchio (n.d.). tive, a Discourse Analysis method was used to analyze these narratives in ways appropriate to this paper's theoretical framework. Discourse Analysis is a broad method that analyzes the meaning behind forms of verbal expression, such as word choice, and non-verbal expression, such as responding to a research question with emotion or change of subject (Gill, 2000). Discourse Analysis was chosen to analyze the interview data because the method pairs well with semi-structured interviews; both illuminate how interviewees emphasize issues such as environmental philosophy, personal values, and cultural tradition. Because the research examines potentially sensitive issues such as farm economic stability, personal identity, and community relations, pairing Rapid Rural Assessment methodology with Discourse Analysis was considered effective for capturing all the ways that communication is used to give meaning to these issues, and filtering these responses through the paper's theoretical framework.

Finally, preliminary results of this research were presented to the interviewees and other agricultural stakeholders at a public forum in Garfagnana on July 31, 2015, in which the stakeholders provided feedback and confirmed the trajectory of the research. Follow-up interviews, additional literature review, and online research followed the field research period.

\section{Historical Socio-ecological Dynamics and Agricultural Practices in Garfagnana}

The mountainous geography of Garfagnana has historically differentiated it from the rest of Tuscany, with important implications for the family farming systems of the territory. The 15 municipalities of Garfagnana are nestled among jutting mountains of the Apuan Alps and the Apennine mountain ranges, which accounts for more marginal soils associated with erosion-prone areas (Figure 1). This geography permits limited consolidation of contiguous farmland and has led 
to small farm plots, restricting the extensive olive, wheat, and vineyard production found in other parts of Tuscany (Camilli \& Pieroni, 2016; Mantino $\&$ Vanni, 2018). For the small-scale family farmers who historically have inhabited Garfagnana, this geographical constraint can be considered a mixed blessing: the terrain has reduced competition between smaller and larger producers over access to land, but limits successful small-scale producers from scaling up their enterprises.

Over the past century, the ways in which small-scale farmers have adapted to this geography have changed dramatically. In the early 1900s, the territory consisted primarily of small-scale subsistence sharecroppers, cultivating chestnuts, barley, potatoes, and small-scale livestock for home consumption (I. Poli, personal communication, July, 2015). Standards of living were low, pushing many families to emigrate from Garfagnana in search of employment opportunities, beginning in the 1920s. With the rise of Fascism in Italy and the beginning of World War II, the Italian government began to prioritize domestic food security, in particular the production of wheat (I. Poli, personal communication, July, 2015), through subsidized agricultural production. In Garfagnana, the government support led to extensive agricultural cultivation of commodity crops on marginal lands, causing the mountainous environment to be cultivated "like a garden," despite it being ill-suited for these practices (I. Poli, personal communication, July, 2015). The war economy temporarily sustained the rural communities of Garfagnana (which still remained relatively poor), but with the end of World War II, the Italian economy collapsed, the wheat subsidy system ended, and much of the agricultural infrastructure in the region was destroyed.

With the collapse of the wheat market, many Garfagnana family farmers re-oriented toward more diversified and subsistence-based production systems, although their efforts were challenged by limited government support and lack of adequate agricultural infrastructure. By the 1950s and 1960s, in part due to economic stimulus from the
Marshall $\operatorname{Plan}^{5}$, new mining and metal industries developed in the regions of Tuscany south of Garfagnana, drawing a second wave of emigration out of the territory (I. Poli, personal communication, July, 2015). Since the 1960s, the population of Garfagnana has decreased $34 \%$ while the population of Tuscany as a whole has increased (I. Poli, personal communication, July, 2015; Rovai \& Andreoli, 2016). This emigration corresponds closely to sharp decreases in the number of farms $(72.9 \%)$ and amount of Utilized Agricultural Area (54.3\%) in Garfagnana from 1982 to 2010, again at rates higher than the Tuscan average (Rovai \& Andreoli, 2016). During this period a significant amount of marginal agricultural land in Garfagnana, previously supported by World War II Fascist agricultural subsidies, was abandoned and left to become unmanaged forest, which remains today (I. Poli, personal communication, July, 2015; Rovai \& Andreoli, 2016). The depopulation trend in Garfagnana over the past 50 years has contributed to the shift toward place-based multifunctional agriculture in two ways. First, the relationship between rural Garfagnana communities and the growing prominence of the encroaching unmanaged forest is viewed by local farmers, politicians, and academics very negatively. Many elders in Garfagnana remember when the landscape was more thoroughly managed in the 1940s and 1950s, such as a local agronomist who characterized the expansion of the forest as "shameful" (I. Poli, personal communication, July, 2015). This current loss of control over the landscape is associated with increases in erosion, flooding, destruction of agricultural land and harvests by wildlife, and a general lack of societal orderliness (I. Poli, personal communication, July, 2015). Wilson (2008) characterizes this phenomenon of comparing agro-ecological management systems, with associated strong moralistic values, as "system memory" in which "a system carries with it the memory_or in a more negative sense the 'baggage' — of previous decision-making trajectories (including missed opportunities and 'wrong' pathway choices but, at times, also highly

5 The Marshall Plan was a U.S. development initiative, championed by Secretary of State George C. Marshall, to rebuild the infrastructure and economies of Europe after World War II. The Marshall Plan was implemented through the Economic Cooperation Act of 1948 (www.archives.gov/exhibits/featured-documents/marshall-plan). 
'positive' choices)" (p. 11). In this case, the generations that remember the past agricultural productionist history of Garfagnana view it highly positively, and all current agricultural development pathways are compared to that period. As a consequence of this socio-ecological 'system memory', efforts by new farmers to reclaim abandoned agricultural land are generally supported by the local community, as they are considered part of a process of re-establishing societal control over an unmanaged nature. Second, in more practical terms, the increased proximity between the Garfagnana communities and the unmanaged forest has impacted farmer practices. Local agronomists explained that with the growth of the forest, a denser tree canopy has increasingly blocked sunlight from reaching the forest floor. This has led to fewer forage plants for forest animals and pushed the wildlife into agricultural areas in search of food, causing significant damage to crops (I. Poli, personal communication, July, 2015). This ecological process has had a range of impacts on farmers, including forcing farmers to invest more in costly fencing to keep wildlife out of fields (Maestà della Formica, personal communication, July, 2015); changing the variety of wildflowers in the area, altering the traditional flavors of locally produced honey (A. Pieroni, personal communication, July, 2015); and, for some farmers, creating access to new wild forest products, which have offered new market opportunities (Maestà della Formica, personal communication, July, 2015). Considering these historical demographic changes and their impacts on socio-ecological relations, the following three case-study farms illustrate how family farmers in Garfagnana are engaged in place-based multifunctional agriculture.

\section{Place-based Multifunctional Agriculture through Three Case-Study Farms}

\section{Reshaping Historical Nature-Society Dichotomies Through Agroecological Practices}

The first case-study farm is Maestà della Formica, a one-hectare farm located on a large mountain plateau surrounded by the Parco Alpi Apuane (Park of the Apuan Alps), near the village of Careggine. The farm is run by three young men who produce high- quality fruits, grapes, and nuts, which they process into jams, syrups, pickles, candies, fruit spreads, and Riesling wine, which are sold locally and in regional markets in the nearby city of Lucca, where the farmers are originally from. The farm is in its infancy, having been started in 2012, but is perhaps this study's best example of place-based multifunctional agriculture.

Maestà della Formica's geographical position is an important factor in shaping a range of its multifunctional and place-based characteristics. The farm is on reclaimed agricultural land surrounded by the Parco Alpi Apuane. The farmers indicated that this location has been instrumental in gaining strong support from the local community because their agricultural activities are viewed as a kind of revalorization of an area that had been gradually taken over by the Parco Alpi Apuane forest. The farmers emphasized that approval from the local community was an important form of social capital for them and helped to sustain their farm in noncapitalist ways, such as by receiving favors and non-monetary support from community members and increased word-of-mouth marketing of their products. The farmers characterized the support as particularly important because they did not grow up in the community, which they said is insular and usually hesitant to accept outsiders. The community thus sees Maestà della Formica as a buffer between wild nature and organized society, providing a kind of public good to the community. This symbolic intermediary role of the farm in the local community's historical relationship with the surrounding forest in turn provides the basis of the farm's strong social and environmental capital. Furthermore, this role embeds the farm in the community by shaping its socio-ecological relations in the territory.

Maestà della Formica can also be characterized as a multifunctional farm in terms of its on-farm production practices and weak integration in capitalist markets. Although immersed in a community culture that views nature as an adversarial force to be managed, the farmers have a more balanced relationship with the environment, as reflected by their agroecological practices. The three farmers emphasize their strong biodynamic philosophy, which promotes a reciprocal relationship with 
nature by never applying chemicals to crops, using very limited organic farm inputs, and building soil fertility. On a practical level, the farmers choose to practice biodynamic agriculture for the clear environmental benefits (i.e., greater environmental capital), which they claim improves their farm through better yields, improved soil-water retention, reduced risk of erosion, and diminished costs of agricultural inputs. But while the Maestà della Formica farmers invest heavily in these biodynamic practices, in which nature is seen as a regenerative "partner" in agricultural production, they do so with an interestingly non-capitalist orientation. Although the farmers could potentially receive higher market prices with the Bio/Organic or Biodynamic market labels, they choose not to use them. Their reasoning for this choice involves their attention to striking a balance between their goals of investing in agroecological practices and maintaining close community relations in their village. For example, when engaging with older agronomists in the community, the farmers found that these more conventional local experts advised them against biodynamic practices, which they did not see as 'modern.' Publically ignoring the advice of the local agronomists would potentially negatively impact the young farmers' reputation in the community, but at the same time they were unwilling to give up their biodynamic philosophy. To mediate this situation, the farmers chose to maintain their agroecological practices, thereby benefiting from strong environmental capital at the farm level, but not to market their products with these labels so as not to oppose the local agronomists publicly. From a multifunctional theory perspective, this approach of investing in socio-ecological sustainability and social capital over potential profits from market labels is closely in line with the multifunctional characteristics of weak integration in capitalist economic systems and investment in environmental capital discussed by Wilson (2008).

In addition to its environmentally sustainable production practices, Maestà della Formica aligns with the multifunctionality characteristics of low productivity and farm diversification (Wilson, 2008). The farm produces on only one hectare of land and does not use intensive production techniques: it produces on average 3,500 liters of berries and nuts per year from 5,000 plants and trees (Maestà della Formica, personal communication, July, 2015). This limited production does not economically sustain the livelihoods of the three farmers, but the farmers have found innovative ways to diversify their farm activities to create nonproductionist income streams and reduce farm processing costs. For example, being located close to the Parco Alpi Apuane, the farmers have developed a business relationship with the park administration to trade educational lectures on sustainable farming and cooking techniques for park visitors in exchange for use of park buildings for processing their fruits. In this way, the farmers build social capital with the local administration and diversify their farm activities. Furthermore, this education role expands the activities of farm in its relations with the broader public, enabling the farmers to act as kind of spokespeople for the territory's sustainability-oriented agricultural community.

In summary, Maestà della Formica demonstrates several strong multifunctional characteristics through its investment in biodynamic farming practices, low productivity and farm diversification strategies, and weak integration in capitalist markets. While all these practices illustrate the farmers' multifunctional approach, their place-based nature is unique. By carefully positioning themselves as intermediators between the community and the Parco Alpi Apuane forest, the farmers are able to strengthen their social relations with the community without having to sacrifice their biodynamic approach to farming and their relations with the local ecosystem. In this way, the farmers are gradually shaping local perceptions of family farming as well as community socio-ecological relations.

\section{Revalorization of Territorial Resources and Engagement with Local Institutions}

The second case-study farm is Azienda Agricola Cerasa, located on seven hectares in a remote and mountainous area of the municipality of Pieve Fosciana. The main activities of Azienda Agricola Cerasa are sheep breeding, wool processing, and production of cheese and lamb. The farm also runs a small restaurant and carries out a number of cultural activities, including educational visits for 
schools. Eco-tourists make up an important segment of Azienda Agricola Cerasa's customer base (Azienda Agricola Cerasa, personal communication, July, 2015; Camilli \& Pieroni, 2016). Established in the early 1970s, Azienda Agricola Cerasa began as a diversified small-scale livestock farm, raising sheep for milk (mostly for pecorino cheese), wool, and meat, which was typical of many small-scale family farms in Garfagnana. But in the 1980s, the Italian livestock sector began to be more concentrated, with larger producers pushing many small-scale farmers out of the sector and forcing others to adapt to the more competitive market environment by changing production techniques or scaling up production (Camilli \& Pieroni, 2016; Societa' Agricola Filippi, personal communication, July, 2015). As part of this trend, most small-scale sheep farms in Garfagnana, including Azienda Agricola Cerasa, began breeding non-native varieties of sheep that produced more milk, in order to specialize in cheese production. These productionist and specialization strategies by small-scale livestock farms led to a decline of over $93 \%$ of the original stock of the indigenous variety of Garfagnana sheep over the past 60 years, from 60,000 animals to approximately 4,000 today (Azienda Agricola Cerasa, personal communication, July, 2015; Camilli \& Pieroni, 2016). Thus the abandonment of the local breed of Garfagnana sheep, traditionally used for different products and markets, coincided with the loss of diversification, both in terms of products and livestock genetics, on family farms in the region, which in turn became arguably less multifunctional and less place-based. In the case of Azienda Agricola Cerasa, despite these productionist and specialization strategies, the farm struggled to compete economically. So in the early 2000s, the farmer-owners of Azienda Agricola Cerasa decided to partner with local institutions in Garfagnana to implement a number of radical changes in the practices and management of the farm to move toward a more place-based multifunctional agriculture system.

In 2004, the Garfagnana Union of Municipalities decided that reintroducing and revalorizing the indigenous Garfagnana sheep breed would be a local government priority, in an effort to preserve the cultural and bio-genetic heritage of the region and strengthen the territory's family farming sector (Azienda Agricola Cerasa, personal communication, July, 2015; Camilli \& Pieroni, 2016; Mantino \& Vanni, 2018). In interviews, the President of the Union of Municipalities stated that the Garfagnana sheep represented an important part of the agricultural and cultural history of the area. In his perspective, the Union's effort to reintroduce the breed is a symbolic reclamation of this history as well as an effort to build the cultural capital of the territory as a public good. To support this priority, the Union of Municipalities made European Union Common Agricultural Policy funds available to 15 farms willing to shift toward sustainable agriculture practices linked to the territory. Under this program Azienda Agricola Cerasa received public funding to reintroduce and breed the traditional variety of Garfagnana sheep to the region. In 2015, a decade into the program, the farm had 90 sheep, which the farming family indicated was the most sustainable carrying capacity of the farm's mountainous landscape. Given this low farm productivity, the Union of Municipalities agreed to support the income of the farm by providing 80 euros per sheep per year to the farm, representing an important source of (public) revenue for Azienda Agricola Cerasa. This effort toward revalorization of traditional indigenous breeds by Azienda Agricola Cerasa, with support of the Union of Municipalities, corresponds closely with the multifunctionality characteristic of farms producing foods with high, often regionally based symbolic characteristics. (Wilson 2008). Thus Azienda Agricola Cerasa's transition to raising symbolically important agricultural products and building (public) cultural capital for the region represents characteristics of strong multifunctionality and emphasizes the place-based nature of the farm.

While providing public financial support for maintaining indigenous breeds is an interesting example of place-based multifunctional agriculture, Azienda Agricola Cerasa and the Union of Municipalities went further on this development trajectory. In the early 2000s, the original Azienda Agricola Cerasa owners decided to transition the farm ownership to the Union of Municipalities. In this highly unusual move, the Union took control of 
the farm, while providing the main source of farm income through the sheep program subsidies. The farmers were able to continue to live on the property, manage production, and receive income from its activities. In addition, the Union renovated buildings on the farm to provide space to be used as an education facility for visitors interested in learning about the agricultural systems of the Garfagnana territory. In this way, Azienda Agricola Cerasa turned into an agricultural learning center, hosting school groups and sustainable-tourism initiatives, with the Union producing all of the agricultural education materials. Thus educational activities on the farm, directly supported by local government, play an important non-productionist role on the farm and represent a form of farm diversification, which has been described as an important multifunctional characteristic (Wilson 2008). The relationship between Azienda Agricola Cerasa and the local government institutions also highlights the farm's multifunctional nature, as Wilson (2008) has noted that multifunctional farms tend to be strongly embedded in local governance structures.

The unique ownership and management of Azienda Agricola Cerasa, and its reorientation toward educational functions, could be seen as a financial risk-management strategy for the farmers, who were able to stay on the land but lost overall sovereignty of their farm. From another perspective, however, Azienda Agricola Cerasa represents an unconventional public-private partnership in which the farming family was able to re-invest in traditional place-based production practices. In either case (or perhaps in both), today Azienda Agricola Cerasa has become a pilot farm for the development of several projects sponsored by the Union of Municipalities, with the aim of testing place-based multifunctional agriculture production practices, strengthening public engagement with their agricultural history, and leading an agricultural place-branding initiative. Given the organizational set-up of Azienda Agricola Cerasa, the farm represents a different approach to engaging with territorial socio-ecological practices and identities when compared with Maestà della Formica, but is also a clear example of place-based multifunctional agriculture.

\section{Supporting Local Food Systems}

The third case-study farm is Societa' Agricola Filippi, a small-scale dairy, also located in Pieve Fosciana. The farm is managed by two brothers who inherited the farm as the fourth generation of farmers in the family. Societa' Agricola Filippi differs from the other case-study farms in a number of ways: it is the oldest farm analyzed, founded in 1922 by sharecroppers and since passed down through four generations; it is the largest farm analyzed, with a total of 10 hectares (both owned and rented land) in a less mountainous area of Garfagnana; and Societa' Agricola Filippi's productionmarketing orientation is quite different, having the highest productivity of commodity products (milk) and contributing most directly to the Garfagnana food system. The combination of these characteristics makes it the least multifunctional of the three case-study farms, while nevertheless exhibiting several place-based characteristics.

The core agricultural practices of Societa' Agricola Filippi involve 22 Bruna Alpina (Brown Swiss) cows that produce 300 liters of milk per day (Societa' Agricola Filippi, personal communication, July, 2015). The milk is processed and sold in local supermarkets and in raw milk form directly to consumers, while a limited amount of milk is also processed on-farm for products such as cheese, artisanal yogurt, and desserts. The farm is thus characterized as small-scale, but for its size it cannot be considered to have low productivity. Societa' Agricola Filippi's development trajectory from subsistence-oriented production in the1920s to this level of commercial production began in the 1960s, when the father of the current farmers increased the mechanization of the farm to reduce labor costs in response to the increasing concentration of the Italian dairy sector. Like the livestock management decisions of Azienda Agricola Cerasa in the 1980s, Societa' Agricola Filippi also replaced the local Garfagnana variety of livestock (cows in this case) on the farm-which at the time were used for meat, milk, and cheese production - with the Bruna Alpina breed, which has higher production adapted specifically for milk bottling, rather than cheese. Thus the farm became more specialized around milk production and less multifunctional, according to diversification and productivity crite- 
ria (Wilson, 2008). In 2014, Societa' Agricola Filippi continued the farm's trend of infrastructure investment by purchasing milk processing machinery. The equipment allowed the farm to become more vertically integrated and cut milk processing costs, and diversify the number of dairy products sold on-farm. In addition to dairy product diversification through on-farm processing, the farmers have strived to diversify farm activities and sources of income, particularly through specialized cow breeding. This technical skill has lowered the farmers' costs (they no longer have to pay an expert for artificial insemination) and has given them more control over the genetic make-up of their herd, and in turn over the quality of their milk. Societa' Agricola Filippi also provides breeding services to other farms as an alternative revenue stream. As a final diversification activity, the farm provides some on-farm educational activities for schools.

What makes Societa' Agricola Filippi exceptional is its success in maintaining its small-scale structure and economic sustainability in an increasingly concentrated dairy sector. In March 2015, the European Union liberalized the dairy sector by ending the Common Agriculture Policy dairy quota system. The quota system had historically been the policy tool used to manage the supply of milk and stabilize prices at fair levels for dairy producers. The dairy quota system, while complex and far from perfect, allowed many small-scale dairies to survive economically in the European Union, in contrast to their fate in the United States. Dismantling the dairy quota system has led to the overproduction of milk in the European Union, declining dairy farmer incomes, and larger dairies buying out smaller dairies (Societa' Agricola Filippi, personal communication, July, 2015). The Societa' Agricola Filippi farmers said that as milk prices have declined with the removal of the quotas, a dairy farm in Italy typically needs at least 100 cows to have the production scale to survive economically. But Societa' Agricola Filippi, with its 22 cows, has managed to be an exception to this general rule, through a mix of limited multifunctional agriculture practices and significant investment in embedding their farm in the local food system, reflecting their increasingly (if also limited) place-based nature. On this point, the geographical location of
Societa' Agricola Filippi is an important factor: the farm is located on the edge of Pieve Fosciana, with residential buildings surrounding it. This location has been both an impediment and an opportunity; the peri-urban location has restricted the possibility for farm expansion, with little access to nearby pasture land for fodder production or grazing, restricting the farm from growing its herd size, which the farmers specifically stated as a challenge. However, the benefit of proximity to the town is being close to its consumer base. In recent years, the farm has increasingly sold its products locally, with particular attention to promoting on-farm milk sales through a self-service milk dispensary system started in 2008. This specialized machinery allows the Societa' Agricola Filippi to sell raw milk, not found in supermarkets, directly off the farm. This allows them to receive a milk price more than three times the wholesale price. The farm sells its raw milk for one euro per liter; at the time of the interview the wholesale milk price was .32 euros per liter (Societa' Agricola Filippi, personal communication, July, 2015). Although the Societa' Agricola Filippi's milk is not a symbolic product of the region (the cows are not indigenous to Garfagnana), this short food-supply chain allows the farm to market a unique product and provides an opportunity for consumers to interact more intimately with their food system, due to the farm's proximity to the town.

In analyzing how Societa' Agricola Filippi can be considered place-based and multifunctional, as discussed previously strong multifunctional farms are characterized as focused on local food chains and weakly integrated into global capitalist markets (Wilson, 2008). Societa' Agricola Filippi provides the best example of these two characteristics: Of the three case-study farms, Societa' Agricola Filippi has the shortest value-chains, with all of their products marketed to local consumers, rather than to tourists or in other towns in the region. This multifunctional characteristic aligns with other research showing that "farms in peri-urban fringe areas ... [have] ... potential for strongly multifunctional pathways" (Wilson, 2008, p. 5). In contrast to Societa' Agricola Filippi's multifunctional characteristic of strong embeddedness in the local food system, the farm does not clearly meet criteria for 
engagement in local governance systems (Wilson, 2008), as Societa' Agricola Filippi receives limited institutional support. The farmers said that they would like to receive funding from the local government administration to reintroduce the local variety of Garfagnana cow, as was done with the Garfagnana sheep, but the local administration has not signed on to this idea. Although the farmers said they had received support from the Union of Municipalities as well as from the local Breeders Association to install the on-farm milk dispensary system, they said that working with the Union has been difficult because the administration appears uninterested in prioritizing support for the dairy milk sector ${ }^{6}$. Finally, in considering Societa' Agricola Filippi's role in the territory's socio-ecological relations, it is important to note that the farmers expressed a limited environmental philosophy; while they did show understanding and concern for sustainably managing their natural resources (e.g., using crop rotations in their fodder fields), their cows are not pasture-raised and the farm's contribution to a territorial identity appears quite limited. Thus the farm seems to have limited environmental capital, and therefore lacks a typical characteristic of criteria for multifunctionality (Wilson, 2008).

In summary, Societa' Agricola Filippi's focus on moderate dairy productivity and its lack of strong social/cultural capital and strong environmental sustainability practices limits its status as strongly multifunctional. However, the farm is well embedded in the local food system rather than in regional or global markets, and it has some limited diversification activities which contribute toward a multifunctional characterization. Societa' Agricola Filippi has also a limited place-based nature. Its production practices are strongly shaped by its geographical position, which the farmers have wisely used to their advantage to embed the farm in the local food system. On the other hand, the farm's functions are not closely tied to the socio- ecological dynamics and/or identities of the territory. In addition, Societa' Agricola Filippi has limited engagement with local governance systems that help shape these dynamics and identities in Garfagnana. Thus Societa' Agricola Filippi is an important example of small-scale family farming strongly contributing to Garfagnana's local food system, but also exhibiting weak or moderate multifunctional and limited place-based characteristics.

\section{Discussion}

As the three case-study farms demonstrate, smallscale family farmers in Garfagnana display a number of multifunctional agriculture activities which are in line with the framework developed by Wilson (2008). Furthermore, there is evidence that over approximately the past five to ten years ${ }^{7}$, many of these multifunctional farms are becoming increasingly place-based. The five-to- ten-year window is important because it demonstrates that these agricultural and socio-ecological practices are well embedded in the farms and the broader territory, and that the farms have reached a degree of operational stability through a process of placebased multifunctional development. As described by Wilson (2008), the overall multifunctional strength or weakness of a farm falls along a spectrum, without an expectation that any single farm will exhibit all of Wilson's criteria. In considering how each farm can be framed as place-based, there are no specific indicators, but this theory is used as a lens to analyze farm/farmers' relationships with the territory. To summarize how these three casestudy farms align with this paper's theoretical framework, four (non-sequential) core place-based and multifunctional themes, drawing on both sets of theory, are discussed that provide a comparison of how the three case-study farms relate differently to the concepts, and that make the argument for a place-based turn in Garfagnana's multifunctional agricultural development.

\footnotetext{
${ }^{6}$ Reasons for this lack of support likely have to do with the fact that the Garfagnana sheep project was funded by the European Union, so the local government may not have power to allocate other resources to similar projects for other livestock varieties and sectors.

7 Although multifunctional or place-based farming activities rarely have definitive start dates, farmers in each of the case-study examples offered more or less defined times when they began implementing their place-based multifunctional approaches to farming. For Maestà della Formica, this began with the founding of the farm in 2012; for Azienda Agricola Cerasa, it began around 2005; and for Societa' Agricola Filippi, it was around 2008.
} 


\section{Ecological Sustainability and Environmental Capital}

Ecological sustainability and commitment to building environmental capital on-farm are characteristics deemed central to a multifunctional orientation that indicate a difference in farmer values from productionist and profit-driven approaches to farming (Wilson, 2008). These characteristics also relate closely to the place-based theory of Richardson and Weszkalnys (2014), highlighted in the theoretical framework, recognizing the intersectionality of agriculture in shaping socio-ecological relations that can go beyond a simple resource extraction paradigm. In analyzing the case-study farms, all indicated some kind of environmental and nonproductionist philosophy and commitment to environmental capital that framed their farming activities. These concepts are most clearly demonstrated by Maestà della Formica, which applies a strict biodynamic approach despite encountering skepticism from some agricultural experts in their community. It should be noted that Maestà della Formica is also the youngest farm of the three analyzed, which is consistent with a suggestion by Guy (2005), stating that young farmers often act as innovators, as they can be more open-minded about new kinds of agricultural practices and therefore may be more likely to embark on strongly multifunctional pathways which emphasize social relations and environmental sustainability. In terms of environmental sustainability, Maestà della Formica can be considered to be on the stronger end of the multifunctional agriculture spectrum.

Azienda Agricola Cerasa also demonstrates a commitment to environmental sustainability, as indicated by their efforts to maintain a small and sustainable herd size as determined by the local landscape. The agricultural education activities of the farm clearly promote sustainable agriculture practices in a territorial context. But it is important to recognize that these sustainable farming practices were implemented because of the farm's financial crisis, resulting (in part) from trying to compete in more globalized markets with a productionist orientation. Furthermore, these new sustainable farming practices are driven in large part by local institutions rather than a radical change in the farmers' environmental philosophy. Thus Azienda Agricola Cerasa's environmental sustaina- bility characterization can be considered a moderate example on the multifunctional agriculture spectrum.

Finally, Societa' Agricola Filippi exhibits the least emphasis on ecological practices and environmental capital. While the farmers do use crop rotation, their operation is the most conventional, with little indication of steps to offset the environmental impacts of this production approach. Part of this limited environmental capital is likely due to the farm's peri-urban location, which impedes being able to engage in environmentally sustainable production practices such as pasture-based grazing, constraining the farm somewhat toward the productionist paradigm of the conventional dairy sector. Thus Societa' Agricola Filippi can be considered to have weak environmental multifunctional characteristics.

\section{Socio-ecological Relations and Territorial Embeddedness}

Socio-ecological relations and territorial embeddedness, while conceptually broad, are important components of place-based theory when analyzing how farming shapes identities, values, and materialities as described by Escobar (2001), Massey (2004), and Pickerill \& Chatterton (2006) in the theoretical framework. Multifunctional agriculture theory involves these concepts by recognizing the role that geography plays in shaping farming activities, as described by Wilson (2008): "farms in countries with substantial mountainous and other agriculturally disadvantaged areas are more likely to be strongly multifunctional (in the developed world)" as an adaptive strategy when there are fewer productionist opportunities (p. 7). From these placebased and multifunctional theory perspectives, both Maestà della Formica and Azienda Agricola Cerasa offer strong (although quite different) characteristics of socio-ecological relations and territorial embeddedness. Maestà della Formica effectively became a symbolic intermediary between the parkland forest and their local community while also building both the farm's social and environmental capital through this process, which are practices closely aligned with the place-based theory of Healey and Jones (2012). This territorial embeddedness also led to farm diversification activities 
educating the public about sustainable agriculture and food traditions in Garfagnana, in turn playing an important role in shaping community values around place-based agricultural practices.

Azienda Agricola Cerasa also represents an example of strong territorial embeddedness, with its focus on revalorizing the territory's local biodiversity, most specifically the local Garfagnana sheep breed. Furthermore, Azienda Agricola Cerasa's re-orientation as an educational farm and its goal of promoting a regional agricultural 'brand' for Garfagnana demonstrates the farm's strong engagement with the public and role in shaping the territory's agricultural identity, in line with the place-based theory of Richardson and Weszkalnys (2014).

Societa' Agricola Filippi offers a more moderate characterization of place-based development. While the farm's practices and marketing are strongly shaped by its peri-urban location, the farm does not clearly facilitate socio-ecological relations, nor is it deeply embedded in a territorial identity.

\section{Engagement with Local Governance Systems}

Engagement with local governance systems is relevant to both multifunctional agriculture theory (Wilson, 2008) and place-based theory (Pickerill \& Chatterton, 2006). While farms do not need to engage explicitly with local institutions or governance systems to be characterized as place-based, local institutions and governance systems are common fora in which societal values are negotiated and formalized. Clark (2003) supports this point by arguing that the multifunctional pathways of farms are often strongly linked to external drivers such as the policy environment or local governance mechanisms. Analyzing Maestà della Formica in terms of these multifunctional and place-based theories, the farm only moderately meets these criteria. While the farm does collaborate with the local Parco Alpi Apuane administration, its engagement is not extensive, relying more directly on informal relations with the local community and local environment.

Azienda Agricola Cerasa, on the other hand, fits the institution-related features of place-based and multicultural theory very closely, because the Union of Municipalities has been primarily respon- sible for supporting the transition of its agricultural practices from a productionist enterprise to a multifunctional and educational farm. Furthermore, given the farm's unique farm governance system, Azienda Agricola Cerasa can be considered semipublic and highly embedded in the local government and territory's agricultural development strategy.

Societa' Agricola Filippi's engagement with local governance structures and institutions is limited. The farm did receive financial support from the local administration for infrastructure investments, and the farmers indicate a desire to be more engaged with local institutions and stakeholders. In practice, however, the farm appears to be the most independent of these organizations and governance structures compared to the other case-study farms.

\section{Productivity, Diversification, and Relation to Markets}

The final category for analysis involves farm production-marketing characteristics central to multifunctional agriculture and place-based theory, including farm productivity, diversification, and engagement with localized food systems rather than integration in capitalist markets. In the case of Maestà della Formica, the farm meets all of these criteria strongly, with low productivity, diverse production systems, strong investment in territorial products (including local wild fruits), and engagement in non-capitalist economies of exchange. However, the farm also markets its products outside of Garfagnana and thus does not contribute most directly to the local food economy. It should be noted that the farm appears to be the least capital intensive, as well as the least financially autonomous, as none of the farmers were able to fully sustain their livelihoods with revenue from the farm at the time of the interviews.

Azienda Agricola Cerasa, similarly, meets all the criteria strongly, with clear dedication to low productivity, farm diversification, and territorial products. At the same time, the farm does not strongly contribute to the local food system, with tourists and European Union funding providing a significant amount of the farm revenue.

Societa' Agricola Filippi again has mixed results. The small-scale dairy has moderate productivity and few farm diversification activities, with- 
out producing symbolic or territorial products, thus limiting its multifunctional characterization. However, the farm invests heavily in on-farm direct marketing to the local community and is also weakly integrated in global capitalist markets, which align it with Wilson's multifunctional criteria (2008).

\section{Conclusion}

Analyzing the farming practices and place-based relations of Maestà della Formica, Azienda Agricola Cerasa, and Societa' Agricola Filippi, this paper argues that these three case-studies represent different forms of multifunctional agriculture on the spectrum of Wilson's theory (2008). In each case, the farmers and farms are redefining themselves beyond a conventional productionist and profitoriented approach by reorienting their socioecological relations, farm management, products and markets toward a more diverse and noncapitalist set of agricultural practices. All three farms have intentionally linked these multifunctional practices in some way to the Garfagnana territory, giving them a range of place-based characteristics as described by Escobar (2001), Massey (2004), and Richardson \& Weszkalnys (2014) and highlighted in this paper's theoretical framework. It is also important to note that local institutions are a moderate or important factor in the farms demonstrating the most strongly multifunctional and place-based characteristics (Maestà della Formica and Azienda Agricola Cerasa), which raises important questions for future research on the role(s) of local institutions in facilitating placebased development. The farm arguably most embedded in the local food system (Societa' Agricola Filippi) was the least clearly multifunctional, which also has policy implications.

The place-based turn in these farms' multifunctional agricultural activities indicate that these small-scale farmers not only thrive through a diverse range of social, economic, and environmental roles, but also critically contribute to the vibrancy of their territory's farming sector and rural economy. But there are some clear differences in how the three farms have followed this place-based multifunctional development trajectory, which indicate that structural economic factors also shape farmers' ability to be place-based and engage in multifunctional practices. In Italy, and globally, both livestock and agricultural commodity markets have become highly concentrated and globalized over the past fifty years. It was these concentration and globalization trends, emphasized by the farmers in this research, which pushed many small-scale diversified farms out of the sector in Italy in the 1980s and forced many others to adapt through specialization and productionist strategies, with arguably limited success. This research suggests that these structural economic issues not only continue to undercut family farmers, but also limit livestock and commodity farmers in particular from embarking on strongly place-based multifunctional development pathways. Clark (2005) speaks to these challenges, stating that some kinds of farms are more likely than others to be " 'locked in' to types of agro-food diversification that are framed by the agroindustrial [productivist] model" (p. 495), a phenomenon also known as "path dependency" (Wilson, 2008, p. 10). Livestock and commodity farms are particularly susceptible to this dynamic: "pure arable or livestock lowland farms... are often more likely to embark on weak multifunctionality pathways than mixed lowland farms" (Wilson, 2007 , p. 275). The two commodity and livestock farms of this research appear to be consistent with to characterizations. Azienda Agricola Cerasa's multifunctionality decreased as it struggled in the productionist livestock paradigm until being financially supported by the region's public institutions and reorienting its activities to be more placebased. For Societa' Agricola Filippi, the dairy has tried to avoid being economically undercut by the conventional dairy sector by selling raw milk, but this strategy does not allow for long-term product storage such as the preserved fruits and wines of Maestà della Formica and even the pecorino cheeses and lamb meat produced by Azienda Agricola Cerasa, limiting the ability of the farm to navigate market fluctuations. It is possible to conclude that while place-based and multifunctional development strategies can strongly support the socio-economic vibrancy of small-scale family farmers and their rural communities by re-orienting farm production practices, socio-ecological relations, and territorial embeddedness, these 
development strategies do not necessarily buffer farms from the impacts of the 'agroindustrial [productivist] model.' And particularly for those commodity and livestock farms striving to primarily serve their local food system, place-based and multifunctional development efforts likely need support from local institutions to weather global concentration and productionist trends.

In conclusion, multifunctional agriculture in Garfagnana is not a new phenomenon, but as evidenced by the three case-study farms analyzed, it has taken an increasingly place-based turn in the past five to ten years. By providing a critical illustration of how family farmers facilitate place-based socio-ecological relations, engage in diverse economies (Gibson-Graham, 2008; Gibson-Graham \& Roelvink, 2009), and contribute to shaping territorial identities, this paper argues that these processes sustain both the small-scale farms and the agricultural communities in which they are embedded.
Thus this place-based turn in multifunctional agriculture represents a relatively new development trajectory for the historically small-scale producers of Garfagnana, with important implications for the vitality of local food systems and the family farming sector.

\section{Acknowledgments}

Many thanks to Mario, Gemma, and Ombretta Cavani, Paolo and Alessandro Filippi, Andrea Elmi, Gian Luca Guidi, Marco Raffaelli, Antonella Poli, and Sandro Peroni for your time and insights for this project. Special appreciation to Dr. Paola Scarpellini, Vanessa Malandrin, Dr. Francesco Di Iacovo, Dr. Leo Dvortsin, Dr. Paul Swagemakers, and professor Gianluca Brunori for your guidance and dedication to training young researchers. And, finally, thank you to Dr. Dirk Roep, Dr. Joost Jongerden, and Flora Sonkin for your ongoing place-based support.

\section{References}

Autorità di Bacino Pilota del Fiume Serchio. (n.d.). Inquadramento geografico. Retrieved May 10, 2019, from http://www.autorita.bacinoserchio.it/territorio/inquadramento_geografico

Bocher, M. (2005). The concept of regional governance in different national funding programmes. Institute of Forest Policy \& Nature Conservation, University of Göttingen, Göttingen DE. Retrieved from https://www.fernuni-hagen.de/polis/download/lg1/projektbmvel/regional governance boecher hagen.pdf

Cairol, D., Caudal, E., Nickel, K., Caron, P., \& Kroger, M. (2009). Multifunctionality of agriculture and rural areas as reflected in policies: The importance and relevance of the territorial view. Journal of Environmental Policy \& Planning, 11(4), 269-289. https://doi.org/10.1080/15239080903033846

Camilli, F. \& Pieroni, S. (2016). The Garfagnana model for exploiting agrarian and cultural biodiversity: The white Garfagnana sheep breed, a case study of sustainable local development. In M. Agnoletti \& F. Emanueli (Eds.), Environmental History vol. 5, Biocultural Diversity in Europe (pp. 321-338). Basel CH, Springer. https://doi.org/10.1007/978-3-319-26315-1 17

Clark, J. (2003). Regional innovation systems and economic development: The promotion of multifunctional agriculture in the English East Midlands. Unpublished doctoral dissertation. Department of Geography, University College, London.

Clark, J. (2005). The 'New Associationalism' in agriculture: Agro-food diversification and multifunctional production logics. Journal of Economic Geography, 5(4), 475-498. https://doi.org/10.1093/jnlecg/lbh064

Escobar, A. (2001). Culture sits in places: Reflections on globalism and subaltern strategies of localization. Political Geography, 20(2), 139-174. Retrieved from https://www.journals.elsevier.com/political-geography

Gibson-Graham, J. K. (2008). Diverse economies: Performative practices for 'other worlds.' Progress in Human Geography 32(5), 613-632. https://doi.org/10.1177/0309132508090821

Gibson-Graham, J. K., \& Roelvink, G. (2009). Social innovation for community economies. In D. MacCallum, F. Moulaert, J. Hillier, \& S. V. Haddock (Eds.), Social innovation and territorial development (pp. 25-38). Farnham, UK: Ashgate.

Gill, R. (2000). Qualitative researching with text, image, and sound: Discourse analysis. London, UK: Sage. 
Guy, A. (2005, June). Personal Comment, Thorney Abbey Farm, Southwell, East Midlands, UK. In Wilson, G. (2008). From 'weak' to 'strong' multifunctionality: Conceptualising farm-level multifunctional transitional pathways. Journal of Rural Studies, 24(3), 367-383. https://doi.org/10.1016/j.jrurstud.2007.12.010

Halfacree, K. (2014). Rural space: Constructing a three-fold architecture. In P. Cloke, T. Marsden, \& P. Mooney, Handbook of Rural Studies (pp. 44-62). London: SAGE.

Harvey, D. (1994). The social construction of time and place; a relational theory. Geographical Review of Japan, 67(2), 126-135. https://doi.org/10.4157/gri1984b.67.126

Healey, J., \& Jones, L. (2012). Relational rurals: Some thoughts on relating things and theory in rural studies. Journal of Rural Studies, 28(3), 209-217. https://doi.org/10.1016/j.jrurstud.2012.01.011

Huylenbroeck, G. van, Vandermeulen, V., Mettepenningen, E., \& Verspecht, A. (2007). Multifunctionality of agriculture: A review of definitions, evidence and instruments, Living Reviews in Landscape Research, 1(3), 1-43. https://doi.org/10.12942//rlr-2007-3

Knickel, K., Renting, H., \& Ploeg, J. D. van der, (2004). Multifunctionality in European Agriculture. In F. Brouwer (Ed.), Sustaining agriculture and the rural economy: Governance, policy and multifunctionality (pp. 81-103). Cheltenham, UK: Edward Elgar.

Mantino, F., \& Vanni, F. (2018). The role of localized agri-food systems in the provision of environmental and social benefits in peripheral areas: Evidence from two case studies in Italy. MDPI Agriculture 8(8), 120. https://doi.org/10.3390/agriculture8080120

Massey, D. (1994). Space, place and gender. Cambridge, UK: Polity.

Massey, D. (2004). Geographies of responsibility. Geografiska Annaler (Ser. B), 86(1), 5-18. https://doi.org/10.1111/j.0435-3684.2004.00150.x

Massey, D. (2005). For space. London: SAGE.

McCracken. A., Pretty, W., \& Conway, G. R. (1988). An introduction to rapid rural appraisal for agricultural development. London: International Institute for Environment and Development.

Pickerill, J., \& Chatterton, P. (2006). Notes towards autonomous geographies: Creation, resistance and self-management as survival tactics. Progress in Human Geography, 30(6), 730-746. https://doi.org/10.1177/0309132506071516

Ploeg, J.D. van der, \& Roep, D. (2003). Multifunctionality and rural development: The actual situation in Europe. In G. van Huylenbroeck \& G. Durand (Eds.), Multifunctional agriculture: A new paradigm for European agriculture and rural development (pp. 37-53). Aldershot, UK: Ashgate.

Ray, C. (2002). A mode of production for fragile rural economies: The territorial accumulation of forms of capital. Journal of Rural Studies, 18(3), 225-231. https://doi.org/10.1016/S0743-0167(02)00003-7

Richardson, T., \& Weszkalnys, G. (2014). Introduction: Resource materialities. Anthropological Quarterly, 87(1), 5-30. https://doi.org/10.1353/anq.2014.0007

Rovai, M. \& Andreoli. M. (2016). Combining multifunctionality and ecosystem services into a win-win solution. The case study of the Serchio river basin (Tuscany-Italy). MDPI Agriculture, 6(4), 49. https://doi.org/10.3390/agriculture6040049

Wilson, G. A. (2007). Multifunctional agriculture: A transition theory perspective. Trowbridge, UK: Cromwell.

Wilson, G. A. (2008). From 'weak' to 'strong' multifunctionality: Conceptualising farm-level multifunctional transitional pathways. Journal of Rural Studies, 24(3), 367-383. https://doi.org/10.1016/j.jrurstud.2007.12.010 